\title{
Doctors' Knowledge, Attitude and Objective Adherence with Hypertension Guidelines in Quetta, Pakistan: A Cross-sectional Analytical Study
}

\author{
Mirza Khan ${ }^{1, *}$, Nafees Ahmed ${ }^{1}$, Abdul Wahid ${ }^{1}$, Syed Liaquat Ali Khan ${ }^{1}$, Asad Khan ${ }^{2}$, Zarka Akbar ${ }^{1}$, \\ Palwasha Bibi ${ }^{1}$ \\ ${ }^{1}$ Department of Pharmacy Practice, Faculty of Pharmacy and Health Sciences, University of Balochistan, Quetta, Balochistan, \\ PAKISTAN. \\ ${ }^{2}$ Department of Pharmacy, Quaid-i-Azam University, Islamabad, PAKISTAN.
}

Received: 12 November 2020;

Accepted: 28 December 2020

*Correspondence to:

Dr. Mirza Khan,

Department of Pharmacy Practice, Faculty of Pharmacy and Health Sciences, University of, Balochistan Quetta, Balochistan, PAKISTAN. Email:mirzakhan92@yahoo.com Copyright: (C) the author(s),publisher and licensee Indian Academy of Pharmacists. This is an open-access article distributed under the terms of the Creative Commons Attribution Non-Commercial License, which permits unrestricted non-commercial use, distribution, and reproduction in any medium, provided the original work is properly cited.

\begin{abstract}
Background: There is scarcity of published information about doctors' knowledge, attitude and adherence with hypertension guidelines from Pakistan. Objectives: To evaluate doctors' knowledge, attitude and objective adherence with the recommendations of Clinical Practice Guidelines (CPG) developed by American Society of Hypertension/International Society of Hypertension. Methods: This cross-sectional questionnaire-based study included 95 doctors from various health care facilities in Quetta, Baluchistan to evaluate doctors' knowledge of and attitude towards guidelines. Physicians' endearment with ASH/ISH (2014) guidelines was evaluated by the prescriptions they wrote to 1900 hypertensive individuals ( 20 prescriptions of each enrolled doctor). Data was analysed using SPSS 20. Results: 58.9\% doctors had sufficient knowledge of guidelines. Doctors' with specialization and consultants, doctors of age $>35$ years and who were in clinical practice for $>5$ years had significantly ( $p$-value $<0.05$ ) greater knowledge and more guidelines adherent practices than their counterparts. There was a significant association between doctors' knowledge and practice scores. ( $r s=0.758$, p-value $<0.001$ ). Overall, doctors had positive attitudes towards guidelines. A total of 1385 (72.9\%) prescriptions were judged guidelines adherent. In multivariate analysis, guidelines adherence had statistically significant positive association with the presence of any comorbidity (OR=2.804, $p$-value $<0.001)$, heart failure $(O R=5.101, p$-value $<0.001)$, chronic kidney disease $(O R=2.384$, $p$-value $<0.001)$ and benign prostatic hyperplasia $(O R=3.137, p$-value $=0.009)$ and negative association with diabetes mellitus $(O R=0.265$, p-value<0.001). Conclusion: Only $58.9 \%$ doctors were adequately aware of guidelines recommendations. A fair number of patients (72.9\%) received guidelines adherent prescriptions. Doctors' poor knowledge of guidelines preferred antihypertensive agents in diabetic hypertensive patients reflected in their practices. Key words: Diabetes mellitus, Duration of clinical practice, Guidelines adherence, Hypertension, Pakistan.
\end{abstract}

\section{INTRODUCTION}

Hypertension is a public health problem. An estimated 31.1\% (1390 million) of the world's adult population suffer from high blood pressure ${ }^{[1]}$ resulting in 7.5 million deaths per year. ${ }^{[2]}$ It is estimated that countries with low and middle income (LMIC) harbour $75 \%$ of the global hypertension (HTN) burden. ${ }^{[1,3]}$ Over the past three decades, the hypertension attributed mortality in LMIC has increased by $107 \% .{ }^{[4]}$ Optimal control of hypertension is crucial for preventing cardiovascular and renal diseases. But unfortunately, the rate of hypertension control reported in published literature ranges from $7.7 \%$ in LMIC to $28.4 \%$ in high income countries. ${ }^{[3]}$

To achieve optimal hypertension control, clinical practice guidelines (CPGs) are frequently developed, regularly updated and extensively distributed worldwide. The well formulated and rigorously designed CPGs enhance the standard of care and patients' outcome by introducing the evidence based medicine into practice, reducing the practice variation and health care costs. ${ }^{[5-8]}$ Although, uncontrolled hypertension is extensively correlated with patients' non-adherence to antihypertensive medications and recommended life style modifications, ${ }^{[0]}$ but doctors' non-adherence with guidelines' recommendations are equally contributing to it. ${ }^{[10-16]}$ Guidelines implementation in clinical practice is a multifaceted process. It is affected by various factors including doctors' knowledge, attitude and behaviour towards guidelines, the characteristics of guidelines themselves and its implementation strategies. ${ }^{[17,18]}$ The barriers preventing doctors' adherence to CPGs have been grouped into three domains i.e. (i) knowledge related factors, (ii) attitude related factors, (iii) behaviour related factors like characteristics of guidelines, patients and practice. ${ }^{[17]}$

Pakistan is the world's sixth most populous country. Like other LMIC, prevalence of hypertension and its suboptimal control are on rise in Pakistan. Diabetes Survey of Pakistan (DPS-PAK) 2016-2017 has reported an alarmingly high prevalence of hypertension in the country. ${ }^{[19]}$ According to the survey results, the age-adjusted weighted prevalence of HTN in Pakistan was $46.2 \% 0^{[19]}$ with an optimal hypertension control rate ranging from $12.5 \%$ to $22.3 \% .{ }^{[20,21]}$ For the evaluation of standard of medical care provided to hypertensive population, it is necessary to evaluate doctors' adherence to hypertension management guidelines. Unfortunately, despite 
a high burden hypertension country with poor rate of hypertension control, published information about doctors' familiarity with hypertension guidelines recommendations and their attitude and adherence with these guidelines from Pakistan is scarce. ${ }^{[15]}$ Therefore, the present study is done with the purpose to fill the above mentioned gap.

\section{METHODS}

\section{Design of study, location of study and sample population}

A cross-sectional prospective study was carried out in Quetta, Baluchistan between September 1, 2018 and April 30, 2019. As Quetta is the capital and major city of the less developed, low populated and the largest province by area (Baluchistan) of Pakistan and in close proximity with the war torn Afghanistan, it is a hub of public and private medical facilities for the residents of Baluchistan and border areas of nearby Afghanistan. Therefore, patients from the whole province and adjacent border areas of Afghanistan visit Quetta and attend the public and private health facilities for satisfying their health needs. In order to conduct the current study, medical doctors practicing in public and private health facilities in Quetta city were approached and briefed about the study. Those physicians' who were managing hypertensive patients and agreed to take part in the study by a giving a consent were included in the study.

\section{Assessment of doctors' knowledge of and attitude towards guidelines}

Pakistan don't have published national CPGs for HTN management. Therefore, ASH/ISH guidelines (2014) which are developed specifically for hypertension management all over the globe, irrespective of residents or resources ${ }^{[22]}$ were used as a reference document. In order to evaluate the doctors' knowledge and attitude regarding ASH/ISH guidelines (2014), a previously published valid and reliable questionnaire ${ }^{[23]}$ was adopted and modified accordingly after getting permission from the authors. The modified study tool (Appendix A) was evaluated by an expert panel comprised of four members that is, a general physician, a nephrologist, a cardiologist and a pharmacist for face and content validity. ${ }^{[23]}$ The key check and items response analysis were used to assess the construct validity of the questionnaire. ${ }^{[23,24]}$ For assessing the language check, clarity and reliability of the questionnaire, it was pilot tested on 25 medical doctors other than the final study participants. The Kuder-Richardson coefficient $(K-R 20)=0.781$ and Cronbach's alpha $=0.817$ respectively revealed good internal consistencies of all portions of the questionnaire. Upon test-retest, Pearson's R product moment correlations of 0.821 ( $p$-value $<0.001)$ and $0.834(p$-value $<0.001)$ respectively revealed finest stability of the questionnaire. ${ }^{[23,24]}$

\section{Administration and scoring of questionnaire}

The lead investigator (MK) administered questionnaire to the study participants with a request of filling it immediately. The first portion of questionnaire consisted of eleven multiple choice question related to knowledge about HTN. Score "1" was given to every right answer; whereas, score of "0" was credited to each unanswered and/or wrong question. ${ }^{[23]} \mathrm{A}$ doctor was categorized as having adequate knowledge about the guidelines recommendations if he/she correctly answered $7 / 11(>60 \%)$ questions must including the correct answer about definition of hypertension. ${ }^{[23,25]}$ The attitude assessing portion of questionnaire consisted of six items and the $1^{\text {st }}$ three items were positively opted while the remaining three were reversely keyed. Five point Likert scale was used for scoring these items ranging from "Strongly disagree (score=1) to strongly agree (score=5) and vice versa for last three statements. ${ }^{[23]}$

\section{Assessment of doctors' adherence with ASH/ISH guidelines (2104)}

The doctors' actual prescribing practices were evaluated by noting the prescriptions they wrote to their patients for the treatment of hypertension (20 prescriptions per physician). These prescriptions were then evaluated by comparing with the guidelines recommendations of antihypertensive drugs. A patient was considered hypertensive if it was evident from his/her medical record or taking antihypertensive medications. Patients' medical record was also assessed for identifying any comorbidity. The antihypertensive drugs prescribed to the patients' were first noted down by their generic names and then grouped according to their pharmacological class. Drugs containing a single active pharmaceutical ingredient (API) were categorized as monotherapy, whereas, medications containing 2 or more than 2 API, either two different drugs or in a single fixed dose formulation were categorized as polytherapy. ${ }^{[7,8,23]}$ In order to find acceptable reasons for doctors' nonadherence with guidelines recommendations, patients' medical records were evaluated in detail for adverse events, contraindications and change of previously prescribed ineffective drugs. ${ }^{[7,23]}$ A prescription was classified as adherent to ASH/ISH guidelines (2014) if: ${ }^{[7,23]}$

i. Patient with a particular medical condition received guidelines recommended first-line antihypertensive medication.

ii. Guidelines proposed first-line antihypertensive medications were advised to patients with more than one concurrent underlying condition with no contraindications to their use.

iii. Patient did not received guidelines proposed first-line antihypertensive medication for a specific condition due to adverse event suspected to be caused by that drug or any contraindication to use was present.

Each guidelines adherent prescription was given a score of "1", whereas, score of " 0 " was given to each non-adherent prescription. ${ }^{[23]}$ A correlation was then established between doctors' knowledge, attitude and guidelines adherence score.

\section{Analysis of data}

Data was analysed using Statistical package for social sciences (SPSS version 20). Mann-Whitney U test and Kruskal Wallis tests (wherever applicable) were used to find difference between doctors' knowledge, attitude and guidelines' adherence scores. Doctors' knowledge, attitude and practice scores were correlated by using Spearman rank order correlation. Association between patients' independent variables and guidelines adherence was assessed by sing univariate analysis. Statistically significant variables obtained in Univariate analysis $(p$-value $<0.05)$ were then entered into multivariate binary logistic regression (MVBLR) analysis to get the final model of significant variables with guidelines adherence. Upon multi-collinearity diagnostics, those independent variables which had high correlation (variance inflation factor $=10$ and $/$ or tolerance value $<0.1)$ were eliminated from the model. The value of significance was set at 0.05 .

\section{RESULTS}

Doctors' knowledge, attitude and adherence with ASH/ ISH guidelines (2014)

Out of 125 doctors approached, a total of $95(76 \%)$ doctors agreed to participate in the current study by giving a written consent. $30.81 \pm 6.74$ years was the mean age of sample doctors'. Majority were males $(65.3 \%)$, 
specialists and consultants $(46.3 \%)$ and in practice for less than two years $(46.3 \%)$. Percentage of doctors' correct answers in compliance with recommendations of ASH/ISH guidelines (2014) are given in the Table 1. The mean number of doctors' correct answer was $7.55 \pm 1.73$ (range: 2-11). Based on definition used in the current study, a total of $56(58.9 \%)$ doctors had adequate knowledge of guidelines recommendations.

On the 30 point scale, the doctors' mean attitude score of $19.67 \pm 2.49$ revealed that they had positive attitudes towards ASH/ISH guidelines (2014) shown in Table 2.

Upon evaluating 1900 prescriptions written by 95 enrolled doctors (20 prescriptions/doctor), a total of 1385 (72.9\%) were judged as guidelines' adherent. The average number of guidelines adherent prescription was $14.58 \pm 3.25$ (range 7-19). Doctors who were more than 35 years old had statistically higher knowledge $(p$-value $=0.001)$ and guidelines adherent practice scores $(p$-value $<0.001)$ than their younger counterparts as shown in the Table 3. The results also showed a statistically significant difference in doctors' knowledge, attitude and guidelines adherence practice score based on doctors' designation and duration in practice. Consultants and specialists had significantly higher knowledge $(p$-value $<0.001)$, attitude $(p$-value $=0.009)$ and guidelines adherent practice $(p$-value $=0.001)$ scores than house medical and medical officers. Furthermore, doctors who were practicing for more than five years had significantly higher knowledge $(p$-value $=0.004)$, attitude $(p$-value $=0.025)$ and guidelines adherent practice $(p$-value $=0.001)$ scores than their counterparts. Strong positive association was found between doctors' knowledge and practice scores revealed by Spearman rank correlation (rs $=0.758, p$-value $<0.001)$.

\section{Patients' characteristics and antihypertensive prescribing pattern}

The socio-demographic and clinical particulars of 1900 enrolled patients

\section{Table 1: Percentage of doctors' correct answers in compliance with recommendations of ASH/ISH guidelines (2014).}

\begin{tabular}{|l|l|}
\hline Question & $\begin{array}{l}\text { Correct } \\
\text { answers } \\
\text { No. (\%) }\end{array}$ \\
\hline $\begin{array}{l}\text { Blood pressure value defining hypertension in an adult subject without } \\
\text { any comorbidity }\end{array}$ & $73(76.8)$ \\
\hline $\begin{array}{l}\text { Target BP value in hypertensive patients with comorbidities of diabetes } \\
\text { mellitus and/or chronic kidney disease }\end{array}$ & $61(64.2)$ \\
\hline $\begin{array}{l}\text { The maximum observational period for a patient recently diagnosed } \\
\text { with stage-1 hypertension having no target organ involvement or any } \\
\text { additional risk factor }\end{array}$ & $56(58.9)$ \\
\hline $\begin{array}{l}\text { Antihypertensive drug of choice in a non-black young patient having } \\
\text { stage-1 hypertension without any comorbidity }\end{array}$ & $66(69.5)$ \\
\hline $\begin{array}{l}\text { Antihypertensive drug of choice in a non-black elderly (age } \geq 60 \text { years) } \\
\text { patient having stage-1 hypertension without any comorbidity }\end{array}$ & $56(58.9)$ \\
\hline Antihypertensive drug of choice in diabetic hypertensive patients & $37(38.9)$ \\
\hline $\begin{array}{l}\text { Antihypertensive drug of choice in hypertensive patients with chronic } \\
\text { kidney disease }\end{array}$ & $78(82.1)$ \\
\hline $\begin{array}{l}\text { Antihypertensive drug of choice in hypertensive patients with coronary } \\
\text { heart diseases }\end{array}$ & $63(66.3)$ \\
\hline Antihypertensive drug of choice during pregnancy & $90(94.7)$ \\
\hline Antihypertensive drug of choice in patients with history of stroke & $53(55.8)$ \\
\hline $\begin{array}{l}\text { Antihypertensive drug of choice in patients with benign prostatic } \\
\text { hyperplasia }\end{array}$ & $82(86.3)$ \\
\hline *missing response=5; missing response=1 & (6) \\
\hline
\end{tabular}

in the present study are given in Table 4. The mean age of patients was $53.19 \pm 10.48$ years. They received a median of 3 (range 1-4) antihypertensive drugs with majority $(73.6 \%)$ being on poly-therapy. Among drugs prescribed, Beta receptor blockers $(\mathrm{BB})$ were extensively prescribed antihypertensive class $(48.5 \%)$ followed by angiotensin receptor blockers (38.0\%), angiotensin converting enzyme inhibitors (ACEIs) (34.2\%), calcium channel blockers $(31.8 \%)$ and diuretics $(28.8 \%)$.

\section{Patients' factors associated with receiving guidelines adherent prescriptions}

In univariate analysis it was found that the reception of guidelines adherent prescription had statistically significant association with patients' family history of CVD and suffering from any comorbidity, heart failure, diabetes mellitus, renal disorder and hyperplasia of the prostate gland (BPH) (Table 5). However upon multivariate binary logistic regression analysis, it was found that the reception of guidelines adherent prescription had statistically significant positive association with the presence of any comorbidity $(\mathrm{OR}=2.804, p$-value $<0.001)$, heart failure $(\mathrm{OR}=5.101$, $p$-value $<0.001)$, $\mathrm{CKD}(\mathrm{OR}=2.384, p$-value $<0.001)$ and $\mathrm{BPH}(\mathrm{OR}=3.137, p$-value $=0.009)$, but it was revealed that diabetes mellitus had statistically significant negative association with guidelines adherence $(\mathrm{OR}=0.265$, $p$-value $<0.001)$ (Table 6). Non-significant Hosmer Lemeshow test $(p$-value $=0.374)$ was used as a basis for this model fit overall classification percentage of $74.4 \%$ from classification Table.

\section{DISCUSSION}

According to our information, this is the first study from Baluchistan, Pakistan which evaluated the doctors' knowledge, attitude and adherence with hypertension management guidelines. Based on the definition used in the current study, a total of $58.9 \%$ doctors had adequate knowledge of guidelines recommendations. In comparison, the percentage of doctors who were adequately aware about recommendations of hypertension guidelines was $73 \%$ in Malaysia, ${ }^{[23]} 51.9 \%$ in Sudan, ${ }^{[26]} 49.1 \%$ in Kuwait, ${ }^{[16]} 23 \%$ in Germany ${ }^{[25]}$ and $20.1 \%$ in Italy. ${ }^{[27]}$ In the current study, doctors' with a mean knowledge score of $7.55 \pm 1.73$ on 11 points scale comparatively performed better than the German and Italian doctors with their respective mean knowledge score of 5.3 and 4.9. ${ }^{[25,27]}$ However, this finding of current study is in parallel with a Malaysian study where the doctors mean knowledge score on the similar scale was $7.96 \pm 1.82 .{ }^{[23]}$ In the current study, specialists and consultants, doctors of age $>35$ years and who were in clinical practice for $>5$ years had significantly greater knowledge and more guidelines adherent prescribing practices than their counterparts. Similar to our finding, increase in doctors' age, senior job titles (consultant/specialist) and increased duration of clinical practice were significantly associated with their higher adherence with hypertension guidelines in studies conducted Sudan and Japan. ${ }^{[26,28]}$ Likewise, a Malaysian study also found that consultants and specialists had significantly higher knowledge about recommendations of Malaysian hypertension guidelines. ${ }^{[23]}$ In current study, the overwhelming majority of consultants and specialists were from cardiology and nephrology, where their likely involvement in the management of hypertension could be one of the possible reasons for their greater awareness about guidelines recommendations. Furthermore, comparatively greater exposure to various clinical practice guidelines during their postgraduate trainings, interactions with peers in seminars and conferences and extensive clinical practice could be some of the other possible reasons for this finding. However, in contrast to our finding, an Italian study has reported that increasing doctors' age and clinical practice tenure had negative association with awareness about hypertension guidelines' recommendations. ${ }^{[27]}$ On a 30 points scale, the mean attitude score of $19.67 \pm 2.49$ revealed that the current study participants 
had positive attitudes towards ISH guidelines (2014). Studies conducted among Malaysian and Mongolian doctors have reported similar welcoming attitudes about hypertension guidelines. ${ }^{[23,29]}$ The reputation of ASH and ISH which developed these guidelines and the relevance of these guidelines in all regions of the world irrespective of population or resources ${ }^{[2]}$ could be some of the possible reasons for the doctors' welcoming attitudes towards these guidelines.

Upon evaluating 1900 prescriptions written by 95 doctors enrolled in the current study, a total of $72.9 \%$ were judged guidelines adherent. In MVBLR analysis, the presence of any comorbidity, heart failure, CKD and BPH had statistically significant positive, whereas diabetes mellitus had statistically significant negative association with receiving guidelines adherent prescriptions. In the current study, the percentage of guidelines adherent prescriptions was comparatively higher than that reported by studies conducted in Saudi Arabia (53\%), ${ }^{[30]}$ South Africa $(56.6 \%)^{[31]}$ and Malaysia $(67.1 \%){ }^{[23]}$ This finding can be partly explained by a very high prevalence of a concurrent comorbidity $(90 \%)$ in the current study participants. It has been previously reported that the concurrent clinical conditions of overlapping aetiologies, pathogenesis and management like hypertension, cardiovascular and CKD increases the likelihood of receiving guidelines adherent prescriptions. ${ }^{[23,32,33]}$ Furthermore, as hypertensive patients with heart failure, $\mathrm{CKD}$ and $\mathrm{BPH}$ were treated by consultants and specialists of the respective fields, their greater familiarity about guidelines recommendations observed in the current study is the other possible reason for writing guidelines adherent prescriptions to hypertensive patients with comorbidities. In the current study, the presence of diabetes mellitus emerged as significant risk factor for receiving guidelines divergent prescriptions. While evaluating the doctors' awareness about recommendations of ASH/ISH guidelines (2014), it was observed that only $38.9 \%$ doctors correctly identified ACEIs as guidelines'

\begin{tabular}{|l|l|l|l|l|l|}
\hline Table 2: Doctors' responses towards ASH/ISH guidelines (2014). \\
\hline Statement & $\begin{array}{l}\text { Strongly agree } \\
\text { No. (\%) }\end{array}$ & $\begin{array}{l}\text { Agree } \\
\text { No. (\%) }\end{array}$ & $\begin{array}{l}\text { Undecided } \\
\text { No. (\%) }\end{array}$ & $\begin{array}{l}\text { Disagree } \\
\text { No. (\%) }\end{array}$ & $\begin{array}{l}\text { Strongly } \\
\text { disagree } \\
\text { No. (\%) }\end{array}$ \\
\hline $\begin{array}{l}\text { I have trust in the developing committee and } \\
\text { recommendations of ASH/ISH guidelines (2014)) }\end{array}$ & $9(9.5)$ & $73(76.8)$ & $10(10.5)$ & - & $3(3.2)$ \\
\hline ASH/ISH guidelines (2014) are helpful for doctors & $7(7.4)$ & $72(75.8)$ & $15(15.8)$ & $1(1.1)$ & - \\
\hline $\begin{array}{l}\text { Doctors' adherence with ASH/ISH guidelines } \\
\text { (2014) would produce desired patients' } \\
\text { outcomes* }\end{array}$ & $3(3.2)$ & $62(65.3)$ & $23(24.2)$ & $1(1.1)$ & $1(1.1)$ \\
\hline $\begin{array}{l}\text { ASH/ISH guidelines (2014) are motivated by } \\
\text { desire to cut cost }\end{array}$ & $4(4.2)$ & $45(47.4)$ & $36(37.9)$ & $9(9.5)$ & $1(1.1)$ \\
\hline $\begin{array}{l}\text { ASH/ISH guidelines (2014) decrease doctors' } \\
\text { autonomy** }\end{array}$ & $7(7.4)$ & $27(28.4)$ & $27(28.4)$ & $32(33.7)$ & $1(1.1)$ \\
\hline $\begin{array}{l}\text { ASH/ISH guidelines (2014) are too rigid to apply } \\
\text { in clinical practice }\end{array}$ & $6(6.3)$ & $34(35.8)$ & $22(23.2)$ & $31(32.6)$ & $2(2.1)$ \\
\hline
\end{tabular}

ASH, American Society of Hypertension; ISH, International Society of Hypertension

$*_{\text {missing response }=5 \text {; missing response }=1}$

Table 3: Doctors characteristics' and differences in knowledge, attitude and practice scores.

\begin{tabular}{|c|c|c|c|c|c|c|c|}
\hline \multirow[b]{2}{*}{ Variables } & \multirow[b]{2}{*}{ No. $(\%)$} & \multicolumn{2}{|c|}{ Knowledge score } & \multicolumn{2}{|c|}{ Attitude score } & \multicolumn{2}{|c|}{ Practice score } \\
\hline & & $\begin{array}{l}\text { Mean } \\
\text { rank }\end{array}$ & $p$-value & $\begin{array}{l}\text { Mean } \\
\text { rank }\end{array}$ & $p$-value & $\begin{array}{l}\text { Mean } \\
\text { rank }\end{array}$ & $p$-value \\
\hline $\begin{array}{l}\text { Gender } \\
\text { Female } \\
\text { Male }\end{array}$ & $\begin{array}{l}33(34.7) \\
62(65.3)\end{array}$ & $\begin{array}{l}50.85 \\
46.48\end{array}$ & 0.455 & $\begin{array}{l}51.44 \\
46.17\end{array}$ & 0.370 & $\begin{array}{l}42.61 \\
50.87\end{array}$ & 0.162 \\
\hline $\begin{array}{l}\text { Age (years) } \\
\leq 35 \\
>35\end{array}$ & $\begin{array}{l}76(80.0) \\
19(20.0)\end{array}$ & $\begin{array}{l}43.25 \\
67.00\end{array}$ & 0.001 & $\begin{array}{l}47.82 \\
48.74\end{array}$ & 0.895 & $\begin{array}{l}42.18 \\
71.29\end{array}$ & $<0.001$ \\
\hline $\begin{array}{l}\text { Ethnicity } \\
\text { Pashtun } \\
\text { Baloch } \\
\text { Other }\end{array}$ & $\begin{array}{l}38(40) \\
33(34.7) \\
24(25.3)\end{array}$ & $\begin{array}{l}44.68 \\
46.68 \\
55.06\end{array}$ & 0.311 & $\begin{array}{l}45.00 \\
48.97 \\
51.42\end{array}$ & 0.645 & $\begin{array}{l}44.30 \\
50.39 \\
50.56\end{array}$ & 0.562 \\
\hline $\begin{array}{l}\text { Designation } \\
\text { HMO } \\
\text { MO } \\
\text { Consultants and specialists }\end{array}$ & $\begin{array}{l}25 \\
26 \\
44\end{array}$ & $\begin{array}{l}29.42 \\
47.62 \\
58.78\end{array}$ & $<0.001$ & $\begin{array}{l}36.78 \\
43.81 \\
56.85\end{array}$ & 0.009 & $\begin{array}{l}33.36 \\
44.88 \\
58.16\end{array}$ & 0.001 \\
\hline $\begin{array}{l}\text { Place of graduation } \\
\text { Balochistan } \\
\text { Other provinces }\end{array}$ & $\begin{array}{l}72(75.8) \\
23(24.2)\end{array}$ & $\begin{array}{l}48.88 \\
53.78\end{array}$ & 0.345 & $\begin{array}{l}47.35 \\
51.67\end{array}$ & 0.452 & $\begin{array}{l}41.62 \\
49.88\end{array}$ & 0.163 \\
\hline $\begin{array}{l}\text { Duration of practice (years) } \\
<2 \\
2-5 \\
>5\end{array}$ & $\begin{array}{l}44(46.3) \\
19(20.0) \\
32(33.7)\end{array}$ & $\begin{array}{l}38.67 \\
50.21 \\
59.52\end{array}$ & 0.004 & $\begin{array}{l}43.86 \\
57.89 \\
55.81\end{array}$ & 0.025 & $\begin{array}{l}36.94 \\
54.47 \\
59.39\end{array}$ & 0.001 \\
\hline
\end{tabular}

HMO, house medical officer; MO, medical officer 


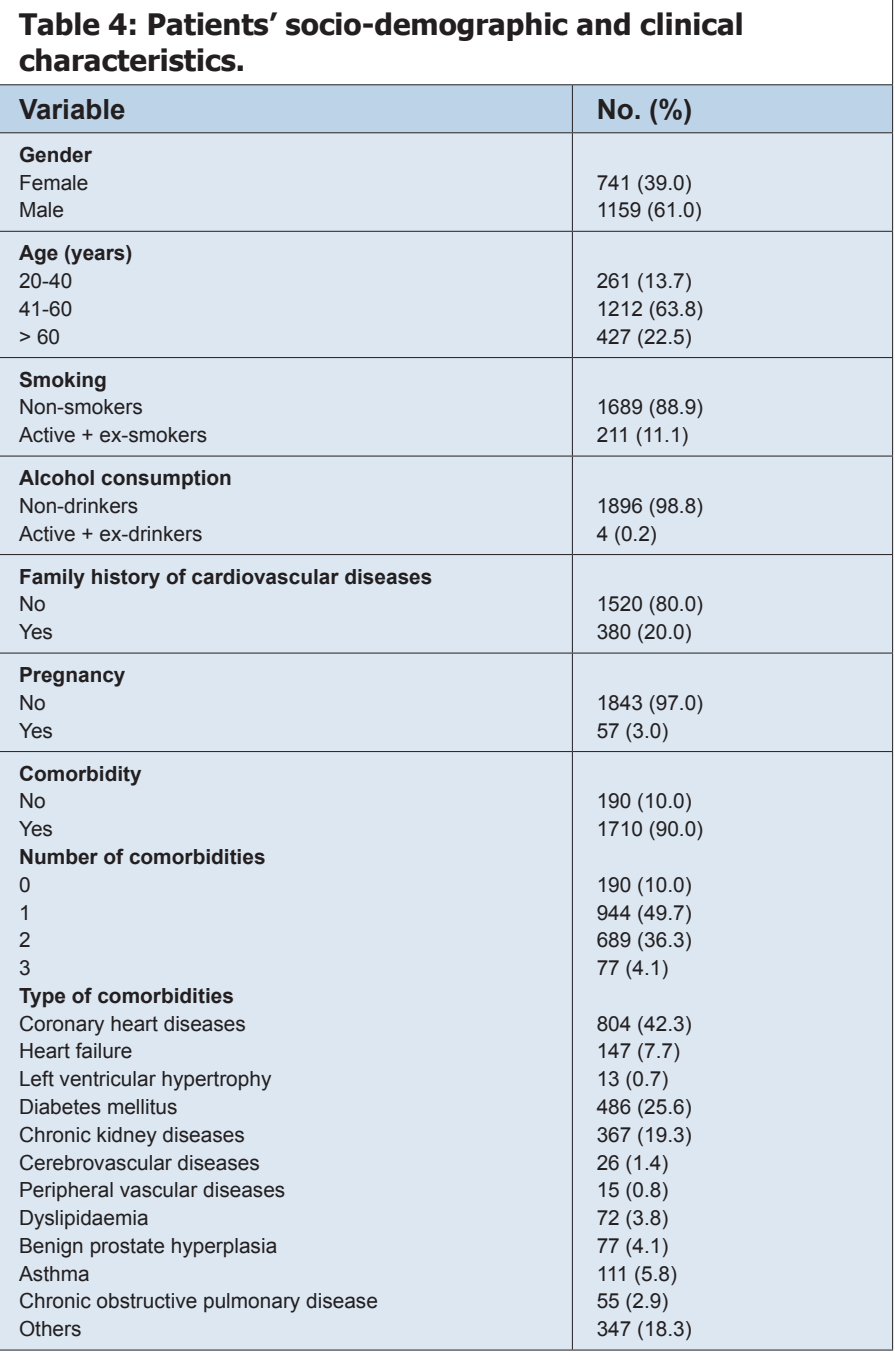

preferred agents for treating hypertension in diabetic patients. This poor familiarity about guidelines' preferred antihypertensive agents in diabetic hypertensive patients could be one of the possible reasons for prescribing guidelines divergent prescriptions in this group of patients. Upon sub-analysis of antihypertensive prescribing pattern in diabetic hypertension patients, we observed that the extensively prescribed drugs to these patients' are BB (45.7\%), followed by ACEIs (47.3\%). Similar underutilization of ACEIs and over-prescription of guidelines discouraged BB to diabetic hypertensive patients have been observed in studies conducted elsewhere. ${ }^{[2,34]}$ The current finding of statistically significant strong positive correlation between the doctors' knowledge and guidelines adherent practice scores is in compliance with Cabana et al. and Pathman et al. models ${ }^{[17,18]}$ and studies conducted elsewhere, ${ }^{[2,35]}$ which state that doctors' greater awareness about guidelines recommendations leads to their adoption and adherence in clinical practice.

\section{CONCLUSION}

The doctors had positive attitudes towards ASH/ISH guidelines (2014), however, only $58.9 \%$ doctors were adequately aware of these guidelines recommendations. A fair number of patients $(72.9 \%)$ received guidelines adherent prescriptions. It was found that doctors' with specialization, consultants, doctors having aged $>35$ years and those were in clinical practice for $>5$ years had significantly greater awareness about guidelines recommendations and more guidelines adherent practices. The doctors' poor
Table 5: Univariate analysis of patients' factors associated with receiving guidelines adherent prescriptions.

\begin{tabular}{|c|c|c|c|c|}
\hline Variable & $\begin{array}{l}\text { Guidelin } \\
\text { prescrip } \\
\text { No } \\
\text { Yes }\end{array}$ & $\begin{array}{l}\text { dherent } \\
\text { No }(\%)\end{array}$ & OR $(95 \% \mathrm{Cl})$ & $p$-value \\
\hline $\begin{array}{l}\text { Gender } \\
\text { Female } \\
\text { Male }\end{array}$ & $\begin{array}{l}208(28.1) \\
307(26.5)\end{array}$ & $\begin{array}{l}533(71.9) \\
852(73.5)\end{array}$ & $\begin{array}{l}\text { Referent } \\
1.083(0.88-1.332)\end{array}$ & 0.449 \\
\hline $\begin{array}{l}\text { Age (years) } \\
20-40 \\
41-60 \\
>60\end{array}$ & $\begin{array}{l}69(24.6) \\
316(26.1) \\
130(30.4)\end{array}$ & $\begin{array}{l}192(73.6) \\
896(73.9) \\
297(69.6)\end{array}$ & $\begin{array}{l}\text { Referent } \\
1.019(0.752-1.380) \\
0.821(0.582-1.158)\end{array}$ & $\begin{array}{l}0.903 \\
0.261\end{array}$ \\
\hline $\begin{array}{l}\text { Smoking } \\
\text { Non-smokers } \\
\text { Active + ex- } \\
\text { smokers }\end{array}$ & $\begin{array}{l}447(26.5) \\
68(32.2)\end{array}$ & $\begin{array}{l}1242(73.5) \\
143(67.8)\end{array}$ & $\begin{array}{l}\text { Referent } \\
0.757(0.556-1.030)\end{array}$ & 0.077 \\
\hline $\begin{array}{l}\text { Any comorbidity } \\
\text { No } \\
\text { Yes }\end{array}$ & $\begin{array}{l}85(44.7) \\
430(25.1)\end{array}$ & $\begin{array}{l}105(55.3) \\
1280(74.9)\end{array}$ & $\begin{array}{l}\text { Referent } \\
2.410(1.774-3.273)\end{array}$ & $<0.001$ \\
\hline $\begin{array}{l}\text { Ischemic heart } \\
\text { disease } \\
\text { No } \\
\text { Yes }\end{array}$ & $\begin{array}{l}282(25.7) \\
233(29.0)\end{array}$ & $\begin{array}{l}814(74.3) \\
571(71.0)\end{array}$ & $\begin{array}{l}\text { Referent } \\
0.849(0.692-1.041)\end{array}$ & 0.116 \\
\hline $\begin{array}{l}\text { Heart failure } \\
\text { No } \\
\text { Yes }\end{array}$ & $\begin{array}{l}506(28.9) \\
9(6.1)\end{array}$ & $\begin{array}{l}1247(71.0) \\
138(93.9)\end{array}$ & $\begin{array}{l}\text { Referent } \\
6.222(3.145-12.308)\end{array}$ & $<0.001$ \\
\hline $\begin{array}{l}\text { Left ventricular } \\
\text { hypertrophy } \\
\text { No } \\
\text { Yes }\end{array}$ & $\begin{array}{l}510(27.0) \\
5(38.5)\end{array}$ & $\begin{array}{l}1377(73.0) \\
8(61.5)\end{array}$ & $\begin{array}{l}\text { Referent } \\
0.593(0.193-1.820)\end{array}$ & 0.361 \\
\hline $\begin{array}{l}\text { Diabetes mellitus } \\
\text { No } \\
\text { Yes }\end{array}$ & $\begin{array}{l}293(20.7) \\
222(45.7)\end{array}$ & $\begin{array}{l}1121(79.7) \\
264(54.3)\end{array}$ & $\begin{array}{l}\text { Referent } \\
0.311(0.249-0.387)\end{array}$ & $<0.001$ \\
\hline $\begin{array}{l}\text { Chronic kidney } \\
\text { disease } \\
\text { No } \\
\text { Yes }\end{array}$ & $\begin{array}{l}460(30.0) \\
55(15.0)\end{array}$ & $\begin{array}{l}1073(70.0) \\
312(85.0)\end{array}$ & $\begin{array}{l}\text { Referent } \\
2.432(1.790-3.305)\end{array}$ & $<0.001$ \\
\hline $\begin{array}{l}\text { Cerebrovascular } \\
\text { disease } \\
\text { No } \\
\text { Yes }\end{array}$ & $\begin{array}{l}504(69.6) \\
11(42.3)\end{array}$ & $\begin{array}{l}1370(73.1) \\
15(57.7)\end{array}$ & $\begin{array}{l}\text { Referent } \\
0.502(0.229-1.100)\end{array}$ & 0.085 \\
\hline $\begin{array}{l}\text { Dyslipidaemia } \\
\text { No } \\
\text { Yes }\end{array}$ & $\begin{array}{l}492(26.9) \\
23(31.9)\end{array}$ & $\begin{array}{l}1336(73.1) \\
49(68.1)\end{array}$ & $\begin{array}{l}\text { Referent } \\
0.785(0.473-1.301)\end{array}$ & 0.347 \\
\hline $\begin{array}{l}\text { Peripheral } \\
\text { vascular disease } \\
\text { No } \\
\text { Yes }\end{array}$ & $\begin{array}{l}513(27.2) \\
2(13.3)\end{array}$ & $\begin{array}{l}1372(72.8) \\
13(86.7)\end{array}$ & $\begin{array}{l}\text { Referent } \\
2.430(0.547-10.807)\end{array}$ & 0.243 \\
\hline $\begin{array}{l}\text { Benign prostatic } \\
\text { hyperplasia } \\
\text { No } \\
\text { Yes }\end{array}$ & $\begin{array}{l}509(27.9) \\
6(7.8)\end{array}$ & $\begin{array}{l}1314(72.1) \\
71(92.2)\end{array}$ & $\begin{array}{l}\text { Referent } \\
4.584(1.980-10.613)\end{array}$ & $<0.001$ \\
\hline $\begin{array}{l}\text { Asthma } \\
\text { No } \\
\text { Yes }\end{array}$ & $\begin{array}{l}484(27.1) \\
31(27.9)\end{array}$ & $\begin{array}{l}1305(72.9) \\
80(72.1)\end{array}$ & $\begin{array}{l}\text { Referent } \\
0.957(0.624-1.668)\end{array}$ & 0.841 \\
\hline $\begin{array}{l}\text { Chronic } \\
\text { obstructive } \\
\text { pulmonary } \\
\text { disease } \\
\text { No } \\
\text { Yes }\end{array}$ & $\begin{array}{l}504(27.3) \\
11(20.0)\end{array}$ & $\begin{array}{l}1341(72.7) \\
44(80.0)\end{array}$ & $\begin{array}{l}\text { Referent } \\
1.503(0.770-2.934)\end{array}$ & 0.232 \\
\hline $\begin{array}{l}\text { Other diseases } \\
\text { No } \\
\text { Yes }\end{array}$ & $\begin{array}{l}414(26.7) \\
101(29.1)\end{array}$ & $\begin{array}{l}1139(73.3) \\
244(70.9)\end{array}$ & $\begin{array}{l}\text { Referent } \\
0.885(0.684-1.145)\end{array}$ & 0.354 \\
\hline
\end{tabular}

$\mathrm{Cl}$, confidence interval; OR, odds ratio 


\begin{tabular}{|c|c|c|c|c|}
\hline Variable & B & SE & OR (95\%Cl) & $p$-value \\
\hline Family history of cardiovascular disease & -0.210 & 0.133 & $0.811(0.625-1.052)$ & 0.115 \\
\hline Comorbidity & 1.031 & 0.169 & $2.804(2.013-3.905)$ & $<0.001$ \\
\hline Heart failure & 1.629 & 0.354 & $5.101(2.548-20.214)$ & $<0.001$ \\
\hline Diabetes mellitus & -1.327 & 0.122 & $0.265(0.209-0.337)$ & $<0.001$ \\
\hline Chronic kidney disease & 0.869 & 0.165 & $2.384(1.724-3.297)$ & $<0.001$ \\
\hline Benign prostatic hyperplasia & 1.143 & 0.436 & $3.137(1.336-7.366)$ & 0.009 \\
\hline
\end{tabular}

$\mathrm{B}$, beta; $\mathrm{Cl}$, confidence interval; OR, odds ratio, $\mathrm{SE}$, standard error

performance in selecting guidelines recommended ACEIs for treating diabetic hypertensive patients reflected in their clinical practice. Failure to prescribe guidelines recommended ACEIs in diabetic hypertensive patients' needs attention and urgent corrective measures. Multidimensional interventions like continued medical education, using reminder tools about guidelines recommended therapy and inclusion of clinical pharmacists in collaborative practice may be helpful in promoting doctors adherence to hypertension guidelines. Medical and house medical officers, doctors of age $<35$ years and those who are in clinical practice $<5$ years should be the preferred target population of these interventions.

As doctors self-reporting practices are subjective to bias, where they overestimate their adherence to guidelines and at instances don't practice what they report, ${ }^{[3]}$ therefore, evaluating the doctors adherence to guidelines by noting their actual prescribing practices in a high number of patients is the major strength of the current study. Moreover, a detailed investigation of patients' medical record was done to find any justification to the guidelines adherence. The major limitations of present study are evaluation of only pharmacological management of hypertension and lack of information on association between guidelines adherence and hypertension control.

\section{ACKNOWLEDGEMENT}

We wish to show gratitude to Dr. Syed Ehsanullah for his assistance during data collection and all the doctors participated in this study.

\section{Ethics approval}

This study was approved by the Research and Ethics committee of Faculty of Pharmacy and Health Sciences University of Baluchistan, Quetta. Written informed consent form was also taken from the enrolled doctors.

\section{CONFLICT OF INTEREST}

The authors declared no competing interests.

\section{Authors' contribution}

This study was conceptualized and designed by NA and MK. MK collected and entered the data. MK and NA analysed the data. NA and MK wrote the manuscript. All the authors reviewed the manuscript critically.

\section{REFERENCES}

1. Mills KT, Stefanescu A, He J. The global epidemiology of hypertension. Nat Rev Nephrol. 2020;16:223-37.

2. Mendis S, Armstrong T, Bettcher D, Branca F, Lauer J, Mace C. Global status report on non communicable diseases 2010. World Health Organization. 2010. Available from: http://www who int/nmh/publications/ncd_report2010/en. 2014.

3. Mills KT, Bundy JD, Kelly TN, Reed JE, Kearney PM, Reynolds K, et al. Global disparities of hypertension prevalence and control: A systematic analysis of population-based studies from 90 countries. Circulation. 2016;134(6):441-50.

4. Forouzanfar MH, Liu P, Roth GA, Ng M, Biryukov S, Marczak L, et al. Global burden of hypertension and systolic blood pressure of at least 110 to $115 \mathrm{~mm}$ Hg, 1990-2015. JAMA. 2017;317(2):165-82.

5. Ament SM, DeGroot JJ, Maessen JM, Dirksen CD, Weijden DVT, Kleijnen J. Sustainability of professionals' adherence to clinical practice guidelines in medical care: A systematic review. BMJ Open. 2015;5(12):e008073.

6. Carter BL, Ardery G, Dawson JD, James PA, Bergus GR, Doucette WR, et al. Physician and pharmacist collaboration to improve blood pressure control. Arch Intern Med. 2009;169(21):1996-2002.

7. Ahmad N, Hassan Y, Tangiisuran B, Meng OL, Aziz NA, Ahmad FuD, et al. Guidelines adherence and hypertension control at a tertiary hospital in Malaysia. J Eval Clin Pract. 2013;19(5):798-804.

8. Ahmad N, Hassan Y, Tangiisuran B, Meng OL, Aziz NA, Khan AH. Guidelines adherence and hypertension control in an outpatient cardiology clinic in Malaysia. Trop J Pharm Res. 2012;11(4):665-72.

9. Abegaz TM, Shehab A, Gebreyohannes EA, Bhagavathula AS, Elnour AA. Nonadherence to antihypertensive drugs: A systematic review and meta-analysis. Medicine. 2017;96(4):e5641.

10. Theodorou M, Stafylas P, Kourlaba G, Kaitelidou D, Maniadakis N, Papademetriou V. Physicians' perceptions and adherence to guidelines for the management of hypertension: A national, multicentre, prospective study. Int J Hypertens. 2012;503821.

11. Bonds DE, Hogan PE, Bertoni AG, Chen H, Clinch CR, Hiott AE, et al. A multifaceted intervention to improve blood pressure control: The Guideline Adherence for Heart Health (GLAD) study. Am Heart J. 2009;157(2):278-84.

12. Hyman DJ, Pavlik VN. Self-reported hypertension treatment practices among primary care physicians: Blood pressure thresholds, drug choices and the role of guidelines and evidence-based medicine. Arch Intern Med. 2000;160(15):2281-6.

13. Ardery G, Carter BL, Milchak JL, Bergus GR, Dawson JD, James PA, et al. Explicit and implicit evaluation of physician adherence to hypertension guidelines. J Clin Hypertens. 2007;9(2):113-9.

14. Raju S, Solomon S, Anns CJ. Assessment of prescribing pattern for hypertension and comparison with JNC-8 guidelines-proposed intervention by clinical pharmacist. J Young Pharm. 2016;8(2):133-5.

15. Jafar TH, Jessani S, Jafary FH, Ishaq M, Orkazai R, Orkazai S, et al. General practitioners' approach to hypertension in urban Pakistan: Disturbing trends in practice. Circulation. 2005;111(10):1278-83.

16. Al-Azzam SI, Najjar RB, Khader YS. Awareness of physicians in Jordan about the treatment of high blood pressure according to the seventh report of the Joint National Committee (JNC VII). Eur J Cardiovasc Nurs. 2007;6(3):223-32.

17. Cabana MD, Rand CS, Powe NR, Wu AW, Wilson MH, Abboud PAC, et al. Why don't physicians follow clinical practice guidelines? A framework for improvement. JAMA. 1999;282(15):1458-65.

18. Pathman DE, Konrad TR, Freed GL, Freeman VA, Koch GG. The awarenessto-adherence model of the steps to clinical guideline compliance: The case of pediatric vaccine recommendations. Med Care. 1996;34:873-89.

19. Basit A, Tanveer S, Fawwad A, Naeem N, Members N. Prevalence and contributing risk factors for hypertension in urban and rural areas of Pakistan; $A$ study from second National Diabetes Survey of Pakistan (NDSP) 2016-2017. Clin Experiment Hypertens. 2020;42(3):218-24.

20. Saleem F, Hassali AA, Shafie AA. Hypertension in Pakistan: Time to take some serious action. Br J Gen Pract. 2010;60(575):449-50. 


\section{Khan, et al.: Doctors' Adherence to Hypertension Guidelines}

21. Shafi ST, Shafi T. A survey of hypertension prevalence, awareness, treatment and control in health screening camps of rural central Punjab, Pakistan. JEGH. 2017;7(2):135-40.

22. Weber MA, Schiffrin EL, White WB, Mann S, Lindholm LH, Kenerson JG, et al. Clinical practice guidelines for the management of hypertension in the community: A statement by the American Society of Hypertension and the International Society of Hypertension. J Hypertens. 2014;32(1):3-15.

23. Ahmad N, Khan AH, Khan I, Khan A, Atif M. Doctors' Knowledge of Hypertension Guidelines Recommendations Reflected in Their Practice. Int J Hypertens. 2018;8524063.

24. Considine J, Botti M, Thomas S. Design, format, validity and reliability of multiple choice questions for use in nursing research and education. Collegian. 2005;12(1):19-24.

25. Hagemeister J, Schneider CA, Barabas S, Schadt R, Wassmer G, Mager G, et al. Hypertension guidelines and their limitations-the impact of physicians' compliance as evaluated by guideline awareness. J Hypertens. 2001;19(11):2079-86.

26. Abdelgadir HS, Elfadul MM, Hamid NH, Noma M. Adherence of doctors to hypertension clinical guidelines in academy charity teaching hospital, Khartoum, Sudan. BMC Health Serv Res. 2019;19(1):309.

27. Cuspidi C, Michev I, Meani S, Severgnini B, Sala C, Salerno M, et al. Awareness of hypertension guidelines in primary care: Results of a regionwide survey in Italy. J Hum Hypertens. 2003;17(8):541-7.

28. Obara T, Ubeda SRG, Ohkubo T, Matsuura H, Ishimitsu T, Takata M, et al. Awareness of the japanese society of hypertension guidelines for the management of hypertension and their use in clinical practices: 2009 survey results. Hypertens
Res. 2015;38(6):400-4.

29. Myanganbayar M, Baatarsuren U, Chen G, Bosurgi R, So G, Campbell NR, et al. Hypertension, knowledge, attitudes and practices of primary care physicians in Ulaanbaatar, Mongolia. J Clin Hypertens. 2018;20(8):1187-92.

30. Alfaleh AS, Alsaidan AMA, Alsaidan AA, Albadi AMM, Wani FA, Banday AH. Adherence of primary health care physicians to hypertension management guidelines in Aljouf Region of Saudi Arabia. Int J Sci Study. 2015;3:83-9.

31. Siko PR, Deventer CV. Compliance with standard treatment guidelines in the management of hypertension: A review of practice of healthcare workers in Potchefstroom, North West Province, South Africa. SAFP. 2017;59(2):72-7.

32. Piette JD, Kerr EA. The impact of comorbid chronic conditions on diabetes care. Diabetes Care. 2006;29(3):725-31.

33. Sales AE, Tipton EF, Levine DA, Houston TK, Kim Y, Allison J, et al. Are comorbidities associated with guideline adherence? The MI-Plus study of Medicare patients. JGIM. 2009;24(11):1205-10.

34. Chan G. Type 2 diabetes mellitus with hypertension at primary healthcare level in Malaysia: Are they managed according to guidelines?. Singapore Med J. 2005;46(3):127-31.

35. Ikeda N, Hasegawa T, Saito I, Saruta T. Awareness of the Japanese Society of Hypertension Guidelines for the Management of Hypertension (JSH 2000) and compliance to its recommendations: surveys in 2000 and 2004. J Hum Hypertens. 2006;20(4):263-6.

36. Adams AS, Soumerai SB, Lomas J, Ross DD. Evidence of self-report bias in assessing adherence to guidelines. Int J Qual Health Care. 1999;11(3):187-92.

Cite this article as: Khan M, Ahmed N, Wahid A, Khan SLA, Khan A, Akbar Z, Bibi P. Doctors' Knowledge, Attitude and Objective Adherence with Hypertension Guidelines in Quetta, Pakistan: A Cross-sectional Analytical Study. J Pharm Pract Community Med. 2020;6(4):57-63. 